\title{
CHARACTERISTICS OF THE INITIAL DENSIFICATION OF SNOW/FIRN IN WILKES LAND, EAST ANTARCTICA
}

\author{
(Abstract) \\ by \\ Qin Dahe \\ (Lanzhou Institute of Glaciology and Geocryology, \\ Academia Sinica, Lanzhou, Gansu, People's Republic of China) \\ and \\ N.W. Young \\ (Australian Antarctic Division, Channel Highway, Kingston, Tasmania 7050, \\ Australia)
}

\section{ABSTRACT}

Fourteen shallow snow/firn cores were drilled with the Polar Ice Coring Office light-weight hand-coring auger in Wilkes Land, along a line approximately long. $111^{\circ} \mathrm{E}$ between lat. $66^{\circ}$ and $74^{\circ} \mathrm{S}$. Five of these cores, all between 20 and $30 \mathrm{~m}$ deep, are studied in detail in this paper: LJ, BJ, GC30, GC40 and GC46. The physical geographical conditions differ at these five stations, but the general trend is for mean annual accumulation rate and mean annual temperature to decrease farther south, with increasing elevation. At the southernmost station, GC46, the mean annual temperature is $-52.5^{\circ} \mathrm{C}$, and accumulation rate is $52 \mathrm{~kg} \mathrm{~m}^{-2} \mathrm{a}^{-1}$

The density measurements of the snow/firn were made in a cold-room at temperatures from $-14^{\circ}$ to $-18^{\circ} \mathrm{C}$, by taking consecutive samples from the core and measuring the mass of each sample of known volume. The characteristics of the initial densification (to a density of $550 \mathrm{~kg} \mathrm{~m}^{-3}$ ) variation in snow/firn density with depth, the densification rate of snow/firn, and the compactive viscosity coefficient of snow/firn - are studied, and the factors affecting this initial densification process are discussed.

The following observations were made and conclusions reached:

1. Plots of all the measurements, from each core, of density against depth showed three different patterns. The first type, typical of the coastal areas, shows a very great variability of density at shallow depth, reducing with an increase in depth. The second, typical of the high inland stations, shows a smaller scatter of densities at shallow depth, again reducing with an increase in depth. The third type is a pattern intermediate between these two. So, the range of density fluctuation with a depth range in any core is greater at the top of the core than at the bottom, and at the same depth in different cores the variation in density is greater where the mean annual temperature is higher.

2. The snow/firn density increases with an increase in depth at all stations, and the densification rate is higher at stations with higher mean annual temperature.

3. The mean density of snow/firn in the top $1 \mathrm{~m}$ decreases farther inland, and this decrease appears to be closely related to the decrease in temperature.

4. The mean densification rate is compared with the mean annual temperature and the mean annual accumulation rate over the past 40 years in the most southerly cores. The mean annual temperature is found to be the more important factor affecting the densification rate in the surface snow/firn on the cold ice sheet.

5. At each station, for $\rho=550 \mathrm{~kg} \mathrm{~m}^{-3}$, a linear relationship is found between $\log$ compactive-viscosity coefficient of snow/firn and mean annual temperature for a constant density. If only stations with a mean annual temperature below $-25^{\circ} \mathrm{C}$ (i.e. no melt features are present in the stratigraphy) are considered, then these results from Wilkes Land are very similar to the results obtained by Nishimura and others (1983) from Mizuho Plateau, East Antarctica.

\section{REFERENCE}

Nishimura, H., and N. Maeno. 1983. Initial stage of densification of snow in Mizuho Plateau, Antarctica. Mem. Natl Inst. Polar Res. Special Issue, 29, 149-158. 